\title{
The Exploitation of Energy Raw Materials and Environmental Protection in the Slovak Republic Legislative
}

\author{
Štefan Kuzevič ${ }^{1, *}$, Marcela Bindzárová Gergel'ová ${ }^{2}$, and Žofia Kuzevičová2 \\ ${ }^{1}$ Institute of Earth Resources, Faculty of Mining, Ecology, Process Control, and Geotechnology, The \\ Technical University of Košice, Letná 9, 04001 Košice, Slovakia \\ ${ }^{2}$ Institute of Geodesy, Cartography and Geographical Information Systems, Faculty of Mining, \\ Ecology, Process Control, and Geotechnology, The Technical University of Košice, Letná 9, 04001 \\ Košice, Slovakia
}

\begin{abstract}
The exploitation and use of energy raw materials is an indispensable need for each country to build the country's economy. In pursuing the sustainable development objectives that Slovakia has pursued, it is necessary to link mining and exploitation and environmental protection, taking into account the rational use of natural resources for the future for future generations. The article focuses on the characteristics of legal norms and strategic documents of Slovakia. With the advancement of raw materials exploitation and processing technology, the share and focus on environmental protection is increasing, contributing to improving the environment of the country and region's population.
\end{abstract}

\section{Introduction}

Mineral resources of each State are an important economic factor and for this reason, it is important to ensure prudent use of in order to ensure the protection and rational use of resources while respecting the basic principles of sustainable development.

Since minerals are classified as non-renewable natural resources, their extraction and processing must take into account the scarcity of their occurrence, the level of mining and processing technologies and the possibility of replacement by other sources. Mining and quarrying must be managed and controlled in accordance with the principles of international environmental law. One way to reduce the consumption of raw materials is also a thorough analysis of possible energy savings [1] and the search for new resources.

Energy is a key factor that affects all sectors of the economy and is one of the cornerstones of the economy. Energy security is part of national security and is one of the tools to ensure sovereignty, political independence and economic security [2].

The efficient use of domestic energy raw materials is part of the National Raw Materials Policy [3], which must create the right conditions for contractors and businesses, tools for effective control over the rational and efficient use of resources, including compliance with applicable mining legislation [4]. Taking into account the current level of industry and the

\footnotetext{
* Corresponding author: stefan.kuzevic@tuke.sk
} 
needs of society, it is not possible to replace coal in metallurgy and coal, oil and gas in the chemical industry.

\section{Materials and Methods}

Exploitation and quarrying should be in line with legislation, whether international or internal, relating to the environment and the rational use of resources, while respecting sustainable development objectives. The right to a favourable environment is a human right a third generation. It is in a group of rights that transcend not only states or continents but is a global problem. It is essential to look at environmental issues and environmental issues in a wider context and not just to solve problems in that country, but to look at them globally.

Most of the legal principles based on international environmental law are respected in the Slovak legislation.

Basic principles:

- Sustainable development,

- The carrying capacity of the territory,

- The acceptable level of environmental pollution,

- Prevention,

- Precaution,

- Integration,

- Polluter pays,

- Remedies at source,

- Law Enforcement,

- Highest protection.

Legislation on environmental protection is also mentioned in the regulation of the highest legal force, namely in the sixth section of the second title "The right to protection of the environment and cultural heritage". So, in addition to people's right to a favourable environment, the environment also has the right to its protection and sustainability for future generations. It is also necessary to take into account the impact on people's quality of life, their health and life expectancy [5]. Each of us is obliged to protect and enhance the environment. At the same time, the state is committed to the conservation of natural resources, ecological balance and effective environmental management and to the protection of designated species of wild plants and wildlife through legislation.

Slovak Government in its policy statement [6] committed to supporting the growth of the quality of the environment as an important obligation and imperative. The government has also committed itself to fulfil the commitments and objectives of sustainable development and the environment adopted at the international level (UN, OECD, and other organizations) and is committed to the implementation of European environmental legislation and to the objectives defined in the 7th General Environmental Action Plan Union's 2020 Agenda [7].

The program is part of the EU's long-term vision and strategy for the direction of the EU to protect the environment and climate by 2050. The goal is to live in 2050 in accordance with the environmental limits of our planet. A key feature of the program is the protection and improvement of natural capital, the promotion of better use of today's resources and the accelerated transition to a low-carbon economy.

The program is based on nine priority objectives:

1. Protect, preserve and enhance the EU's natural capital,

2. To make the EU a low-carbon, resource-efficient and competitive economy

3. Protect EU citizens from environmental pressures and risks to their health and wellbeing;

4. Maximizing the benefits of EU environmental legislation 
5. Improve the knowledge base for environmental policy

6. Ensure investment in the environment and climate policy and set prices correctly

7. Improve environmental integration and policy coherence between the Member States;

8. Support urban sustainability in the EU

9. Increase the effectiveness of the EU in addressing regional and global environmental and climate change challenges.

Caring for the environment is a concept that society has taken to the environment. The aim of care is to maintain or improve its quality with respect to all organisms including man while respecting the principles of sustainable development.

\section{Results and Discussion}

The term "Natural Resources" is defined in the legislation of the Slovak Republic by Act no. 17/1992 Coll. $\$ 7$ "there are those parts of the living or non-living nature that man uses or can use to satisfy his needs". They are divided into renewable and non-renewable resources. Renewable natural resources have the ability to recover in part or in total, either alone or with a human contribution. Non-renewable natural resources are consuming. [8]

Figure 1 shows the ministries and an overview of selected documents dealing with the issues of environmental protection and mineral resources in Slovakia.

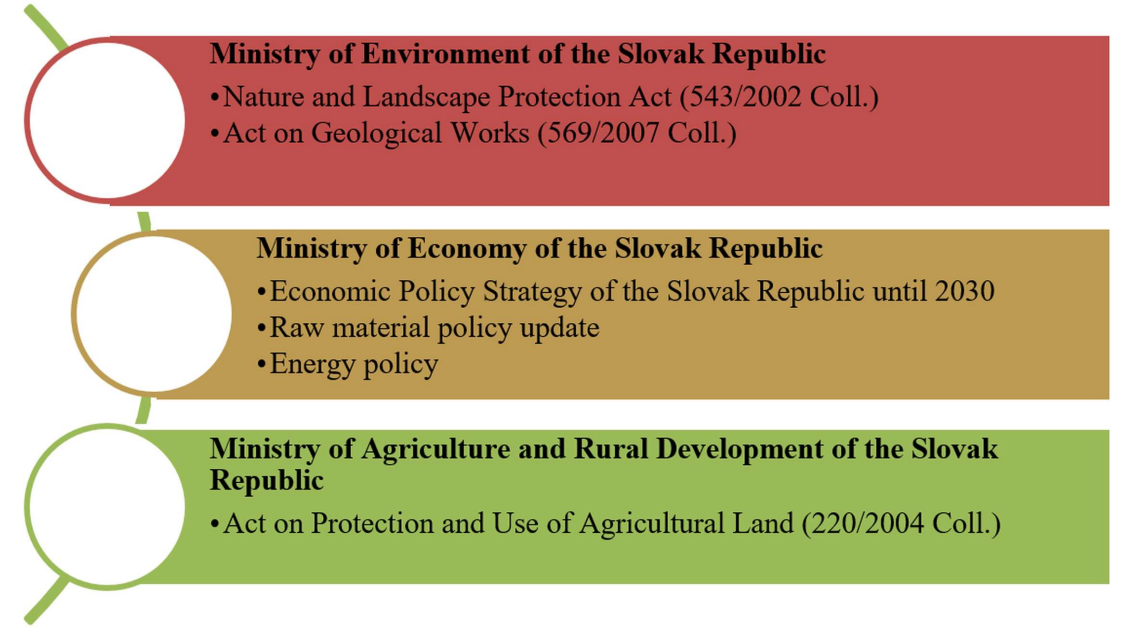

Fig. 1. Basic documents in Slovak legislation.

For successful implementation of the objectives of sustainable development concerning the rational use of natural resources, the development of a concept of sustainable exploitation of rock environment [9]. The document is divided into two parts: mineral resources and geological factors.

Efficient use of domestic energy raw materials is part of the Raw Materials Policy [3], which must create the right conditions for entrepreneurs and companies, tools for effective control over the rational and efficient use of resources, including compliance with applicable mineral mining legislation.

Pursuant to Act no. 44/1988 on the Protection and Utilization of Mineral Resources (Mining Act), minerals are considered to be solid, liquid and gaseous parts of the earth's crust and are divided into reserved and non-reserved. Mineral resources can be understood as those components of the earth's crust (elements, compounds, minerals or rocks) that can be used directly or after treatment in the farm.

Mineral resources are classified as follows: 
- Fuel-energy sources (solid fuels - coal, liquid - oil, gaseous - natural gas, nuclear radioactive elements)

- Ore raw materials

- Non-metallic raw materials.

In Slovakia, there are reserved deposits of energy raw materials, namely Mineral oil, natural gas, brown coal, lignite, uranium, anthracite, and bituminous rocks. Anthracite and bituminous rock deposits are unloaded, and their economic importance is marginal.

- Brown coal and lignite

There are 10 brown coal deposits and 8 lignite deposits in Slovakia. Mining takes place on 3 deposits of brown coal, namely in Nováky, Handlová, Modrý Kameň and on one lignite deposit - Gbely - Dubňany seam.

The estimated geological reserves of lignite and lignite are $1082 \mathrm{Mt}$, of which $9.4 \%$ are estimated to be economically viable [10]. Other stocks are considered unprofitable because of the parameters (stock levels, quality, and mining conditions).

- Oil and gasoline

In Slovakia there are two deposits of non-paraffinic oil (Gbely and Šamorín), 8 deposits of semi-paraffin oil (Jakubov - Dúbrava, Gajary - Baden, Láb, Jakubov, Lipany, Studienka, Plant, Cunín) and nine gasoline deposits (Gajary - Baden, Láb, Ptrukša , Zavod, Banovce nad Ondavou, Senne, Stretava, Trhoviste - Pozdisovce, Trebisov).

Domestic oil production is almost negligible compared to consumption.

- Uranium (Uranium)

There are two uranium deposits in Slovakia, namely Spišská Nová Ves - Novoveská Huta and Košice I. Total reserves are estimated at 10,049 tons of which 6,561 t balance stocks and 3,488 tons of non-balance sheets.

- Natural Gas

There are 30 natural gas deposits in Slovakia. In the area of gas extraction, 103 people were employed in Slovakia in 2015.

In terms of consumption, the Slovak Republic is almost $90 \%$ dependent on imports of primary energy sources: nuclear fuel $(100 \%)$, natural gas $(98 \%)$, oil (99\%) and coal $(68 \%)$. Given the projected $2 \%$ annual increase in global primary energy consumption over the period 2000-2030, it will lead to a shortening of their global stock life to about 50 years for oil, 70 years for gas, 120 years for black coal and 300 years for brown coal. Coal will be considered the most important energy raw material in the future.

Figure 2 shows the evolution of final energy consumption, which differs from gross domestic consumption.

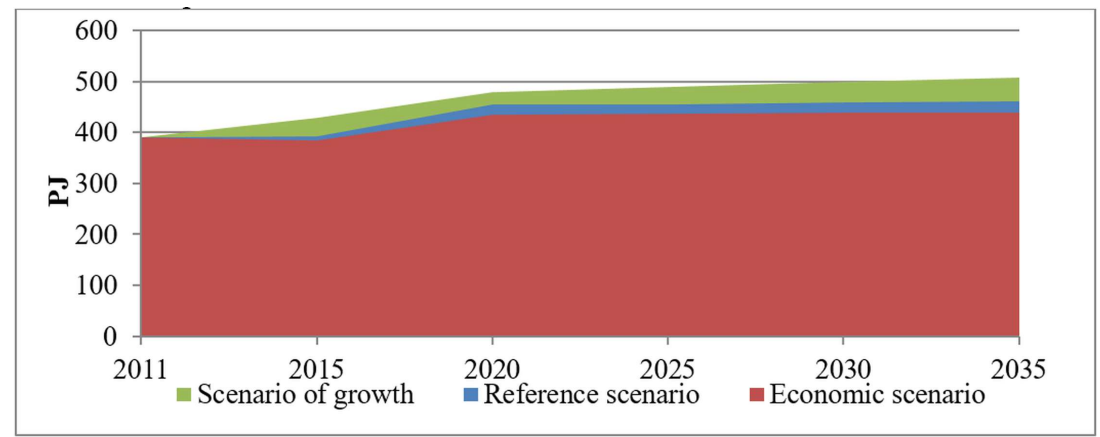

Fig. 2. Scenarios final energy consumption (Prepared in accordance with the Energy Policy). 


\section{Conclusion}

Energy is a fundamental pillar of a society that affects all sectors of the economy and life of the population and is also closely linked to environmental protection. The Slovak Republic is bound by a number of international law documents, some of which have subsequently been implemented into internal law. Slovakia is completely dependent on imports for strategic energy raw materials. In view of this problem, it is essential to promote the diversification of resources and transport, in particular, oil and gas, given the challenges of the past years. At the same time, while respecting the principles of sustainable development and the objectives of the 2030 Agenda, it is necessary to focus on the rational use of mineral resources while looking for possible alternatives to complement or replace them. In order to achieve sustainable development, it is, therefore, necessary to partially change technologies, processes, and habits not only on the production side but also on the consumption side.

\section{References}

1. K. Teplická, M. Taušová. TechCon, 8:2, 35-37 (2012)

2. Energy security strategy of Slovak Republic. URL: http://www.rokovania.sk/Rokovanie.aspx/BodRokovaniaDetail?idMaterial=14372

3. Update Raw Materials Policy of the Slovak Republic for Mineral Resources. URL: http://www.rokovania.sk/Rokovanie.aspx/BodRokovaniaDetail?idMaterial=10191

4. Z. Šimková, M. Cehlár, H. Pavolová. Acta Montanistica Slovaca, 21:3, 208-216 (2016)

5. S. Khouri, M. Cehlár, K. Horanský, K. Transformations in Business and Economics, 16:2B, 638-655 (2017)

6. Program Declaration of the Government of the Slovak Republic for 2016 - 2020 (Republic, Bratislava, 2016)

7. The 7th Environment Action Programme (EAP) with the subtitle "Good Life within the Possibilities of Our Planet". http://ec.europa.eu/environment/pubs/pdf/factsheets/7eap/sk.pdf

8. Act no. 17/1992 Coll. on the environment (Republic, Bratislava, 2007)

9. Ministry of Environment, The concept of sustainable exploitation of rock environment. URL: http://www.rokovania.sk/Rokovanie.aspx/BodRokovaniaDetail?idMaterial=272

10. Baláž, P., Mineralia Slovaca, 45, 225-232 (2013) 